Драгана Д. Милуновић

Народна библиотека

Србије, Београд

dragana.milunovic@nb.rs
Стручни рад

UDK 027.54(497.11)"2020"

616.98:578.834(100)"2020"

https://doi.org/10.18485/bibliotekar.2020.62.2.3

\title{
НАРОДНА БИБЛИОТЕКА СРБИЈЕ У УСЛОВИМА ВАНРЕДНОГ СТАҢА ПРОГЛАШЕНОГ ПОВОДОМ ПАНДЕМИЈЕ ЗАРАЗНЕ БОЛЕСТИ КОВИД-19
}

Сажетак: Рад се бави описом начина организације рада, као и остварених резултата Народне библиотеке Србије током ванредног стања проглашеног услед пандемије заразне болести ковид-19. Описан је начин рада на нивоу појединачних организационих јединица, са посебним нагласком на изазовима који су обухватали рад са корисницима на даљину, обезбеђивању потребне инфраструктуре запосленима за рад на даљину, као и примену епидемиолошких мера заштите запослених, корисника и књижног фонда.

Кључне речи: пандемија, Народна библиотека Србије, епидемиолошке мере.

У складу са Одлуком о проглашењу ванредног стања и Уредбом Владе Републике Србије о организовању рада послодаваца за време ванредног стања, Народна библиотека Србије (НБС) у периоду од 16. марта до 27. априла 2020. године није била отворена за кориснике. Запослени су обављали послове у складу са Решењем о обављању послова ван просторија послодаваца за време ванредног стања. У згради НБС обављани су послови откупа књига, пријема обавезног примерка публикација, уз пратећа дежурства у библиотеци, као и повремене доласке ради обављања хитних послова за које је неопходно физичко присуство у просторијама НБС, а која су утврђивана према потреби. На овакав или сличан начин послове је обављао највећи број националних библиотека у свету, али и других типова библиотека са главним циљем да се сачува здравље запослених.

На основу Уредбе Владе о организовању рада послодаваца за време ванредног стања („Сл. гласник РС” број 31/2020), Уредбе о мерама за време ванредног стања („Сл. гласник РС” број 31/2020, 36/2020, 36/2020, 38/2020, 
39/2020, 43/2020, 447/2020, 49/2020, 53/2020, 56/2020, 57/2020 и 58/2020), Закључка Владе 05 број 53-3259 („Сл. гласник РС” број 58/2020), Препоруке Министарства културе и информисања упућене установама заштите културног наслеђа број 112-01-138/2020-07 од 21. 4. 2020, као и на основу других аката Владе Републике Србије и других надлежних органа донетих за време проглашеног ванредног стања, читаонице Народне библиотеке Србије почеле су да раде од 27. априла 2020. године. Рад је организован под измењеним условима и уз придржавање свих епидемиолошких мера и строгих мера физичког дистанцирања, док је на радна места у згради библиотеке враћен одређени број запослених. Сукцесивно, и сагласно инструкцијама ресорног министарства, на посао у згради враћана је једна по једна група запослених (хронични болесници, као и мајке деце до дванаест година на посао су враћени тек почетком јуна 2020. године).

Начин организације рада у условима ванредног стања, као и реализоване активности у периоду током кога је рад организован од куће биће представљени у овом раду.

\section{Сектор за библиотечко-информациону делатност}

Од ступања на снагу ванредног стања, Одељење обавезног примерка имало је највише свакодневних обавеза које су укључивале дежурства у згради. Наиме, природа посла која подразумева пријем и распоређивање обавезног примерка, издавање потврда о примљеном обавезном примерку за потребе републичког откупа књига захтевала је континуитет у доласцима у библиотеку. Сачуване су комплетне дневне новине које су излазиле у мањем броју издања током ванредног стања, као и различита периодична издања.

Издавачи су редовно похрањивали дигиталне копије обавезног примерка на сервере електронског обавезног примерка (укупно 4.861), а настављено је прикупљање српског интернет домена у опсегу које су допуштали технички услови. Првенствено су сачувани портали које су покренуле владине службе, а везани су за пандемију болести ковид-191 и други портали са блиским садржајем. Током ускршњих празника сачувани су портали хришћанских заједница у Републици Србији, као и исламске заједнице почетком рамазана.

\footnotetext{
https://covid19.rs/, https://www.digitalnasolidarnost.gov.rs/, https://rasporednastave.gov.rs/ index.php, https://budivolonter.gov.rs/
} 
Као члан међународног конзорцијума за очување интернет садржаја (The International Internet Preservation Consortium) Народна библиотека Србије укључила се у пројекат „Novel Coronavirus (2019-nCoV) outbreak” пославши 453 линка ка интернет страницама са припадајућим метаподацима на српском и енглеском језику, који ће бити сачувани на серверима те организације. Битно је истаћи да је на овај начин НБС успела да сачува и одређене интернет странице које није у могућности да прикупи сопственим ресурсима (друштвене мреже итд.).

У Одељењу селективне набавке пријем поклона је обустављен, као и слање наших поклона другим библиотекама. Због немогућности обраде, лекторисања, сортирања књига по дезидератима, договорено је да рад од куће буде усмерен на проверу поште, одговарање на захтеве сарадника и проверу спискова размене и поклона. Обустављено је слање пакета у иностранство, као и одношење већ припремљених пакета у архиву, због гомилања у поштама и како не би дошло до кидања адресница, чиме би се трајно изгубила информација и од кога је пакет и коме упућен. Претраживана је и страна издавачка продукција са циљем идентификације сербике.

Рад са корисницима на даљину представљао је посебну врсту изазова и подразумевао како пружање општих информација на захтев, тако и тематска претраживања база података.

Поред предложене литературе корисници су упућивани и на електронске изворе који су им тренутно доступни, а личне библиотеке библиотекара биле су у служби пружања информација корисницима.

Након релаксације мера, рад са корисницима подразумевао је рад у простору Библиотеке уз придржавање највиших хигијенских стандарда у смислу постављања дезобаријера на све улазе, као и средстава за дезинфекцију руку, употребе заштитних маски и рукавица, као и истицање упутстава за одржавање хигијене на видним местима у корисничком делу зграде. Одржаван је ограничен број корисника и ограничен број запослених у читаоницама и канцеларијама како би се смањио физички контакт и одржала прописана раздаљина од два метра између корисника и запослених, као и корисника међу собом. Процедура наручивања библиотечко-информационе грађе и извора обављана је тако што су захтеви достављани унапред, на имејл адресу pitajtebibliotekara@nb.rs, а преглед захтева обављали су библиотекари и информатори који су спискове наруџбина достављали Одељењу за чување и приступ фондовима. Максималан број јединица грађе које су се могле наручити у једном дану био је ограничен на пет по кориснику, а у случају потребе, корисник је исту грађу могао да користи и наредних дана, уз претходно заказивање термина доласка у Библиотеку. 
Приликом враћања грађе корисник оставља грађу на означено место на пулту, а након сваког враћања грађе пулт се дезинфикује. Враћена грађа коју је корисник одложио одвози се у претходно припремљен простор издвојену просторију за карантин; са овом грађом поступа се у складу са препорукама Одељења за конзервацију и рестаурацију.

Од увођења ванредног стања у Одељењу монографских публикација захтеви за израду CIP-а примани су електронски, а обрађивачи су по потреби одржавали консултације са издавачима. Број обрађених захтева износио је 952, док је додељено 758 ИСБН бројева. И у Одељењу серијских публикација, складу са препорукама, рад на CIP-у и додела ISSN бројева постали су приоритет али обављани су и други послови и то рад на Библиографији Србије - серијске публикације, редакција записа, разрешавање дупликата, као и отварање нових наслова. У Одсеку за аналитичку обраду чланака у периоду рада од куће онлајн су обављани сви послови као током редовног рада, осим рада на ревизији фонда, због физичке недоступности књига. У складу са препорукама, рад на СІР-у и овде је био приоритет и кроз дневно дежурство и расподелу материјала сви чланци из часописа који су стизали на СIP преко заједничког имејл налога обрађени су и класификовани без икаквог застоја и временског одгађања. У Одељењу посебних фондова прилив материјала за СIP се умногоме смањио, док на почетку пандемије није било захтева за ISMN и ISAN. Обављани су послови редакције записа у бази COBIB.SR, као и унос и редакција у бази CONOR. У бази ЕКРААН - електронски каталог рукописа и архивалија редиговани су постојећи записи и урађени нови нормативни записи. Настављен је рад на приређивању издања преписке Љубомира и Анушке Мицић, као и рукописа „Бекство мога оца из Турске у Србију”, који су у издавачком плану у оквиру едиције „Жива прошлост”.

У ванредним околностима Одељење за научне информације је несметано обављало све своје делатности, везане за све програмске активности. Предност овог одељења огледала се у томе што су све активности погодне за рад на даљину.

Настављен је рад на два главна програма: КоБСОН - Конзорцијум библиотека Србије за обједињену набавку и DOISerbia - промоција научних часописа који излазе у Србији и њихово укључивање у међународну размену, као и обављање редовних активности, које обухватају: одржавање веб-странице КоБСОН-а, Фејсбук и Твитер странице, претраживање доступних електронских извора за потребе корисника, дневна комуникација са страним издавачима и корисницима, праћење и објављивање свих статистичких података о коришћењу претплаћених извора, одржавање 
сервиса Наши у WoS, одржавање дигиталног репозиторијума Народне библиотеке Србије. У оквиру иницијативе Дигитална солидарност послати су подаци о два сервиса - DoiSerbia и DoiSerbia PhD.

Библиографско одељење махом је било ангажовано на редакцији записа у локалном и узајамном каталогу, а који се односе на Библиотеку манастира Хиландара, Библиотеку Арсенија Стојковића у Сентандреји, као и библиографију периодике.

Библиотечко пословање и организација у Одељењу за чување и приступ фондовима састојало се од провере инвентарних бројева након спроведене електронске ревизије фонда. Списак за проверу и исправку инвентарних бројева је садржао 10.000 јединица, а запослени су на кућним рачунарима инсталирали COBISS платформу, преко које су прегледали и исправљали инвентарне бројеве. У оквиру Одељења постоји и књиговезачка радионица са четири запослена. С обзиром да је реч о колегама са вишедеценијским искуством, свако до њих код куће има приручну радионицу са елементарним прибором којим могу да се повезују књиге. На овај начин преповезано је око 400 публикација.

Одељење за заштиту, конзервацију и рестаурацију по увођењу ванредног стања изменило је праксу рада у лабораторији, сходно новонасталој ситуацији, тако да су организована дежурства у лабораторији (при чему је настављен рад на угроженој књижној и некњижној грађи), док је остатак тима упућен на рад од куће. Делу радника омогућен је практичан рад (на повезу, тамо где постоје услови), док је главни акценат бачен на научно-истраживачки рад у пољу заштите писане баштине, а рад из области превентивне заштите старе и ретке библиотечке грађе се спроводио у лабораторији. У светлу препорука да се омогући рад библиотека са корисницима, конзерватори су се бавили и истраживањем метода заштите грађе и запослених у условима рада под пандемијом. Остварени су контакти са многим међународним институцијама културе, као и колегама конзерваторима из ових институција који су пренели своја искуства у борби против вируса Сарс-Ков-2. Консултовали смо се и са колегама из националних институција културе у Србији (Архив Србије, Народни музеј, Музеј савремене уметности, Универзитетска библиотека, Музеј Николе Тесле) ради размене искустава и мишљења. На основу светске праксе, као и размене мишљења са колегама из струке, Одељење за заштиту је сачинило упутство за руковање библиотечком грађом у време пандемије, а у циљу заштите како грађе тако и људског здравља.

По ублажавању мера и касније по укидању ванредног стања, конзерваторска служба је отпочела практични рад на заштити културне баштине 
у лабораторији Народне библиотеке Србије, повратком радника у етапама. Повратком у лабораторију настављен је конзерваторско рестаураторски рад на заштити културних добара писаних на папиру и пергаменту, према раније усвојеном плану и програму. Конзервира се следећа грађа: збирка старе и ретке књиге Библиотеке Глигорије Возаревић, збирка међународних уговора Министарства спољњих послова, збирка архивалија Архива САНУ, као и угрожена књижна грађа фонда НБС.

Рад Одељења за археографију у условима ванредног стања одвијао се у суженом обиму. Неке активности су редуковане и прилагођене раду од куће, док су оне које захтевају непосредан рад са рукописима и старим штампаним књигама, у потпуности обустављене (прикупљање грађе за археографску обраду, експертиза, припрема за конзервацију...) На лицу места су провераване једино вредности микроклиматских услова у Трезору, и то редовно; у ово су укључени сарадници Одељења за археографију и начелник Одељења за техничко-безбедносне послове.

Од куће се радило на пројекту „Опис српских рукописних књига у иностраним збиркама”, којим руководи Библиотека Српске патријаршије, а суфинансира га Министарство културе и информисања, при чему је за штампу приређен део археографског описа (кодиколошки опис, опис садржине, маргиналије и записи) 21 српске рукописне књиге у Мађарској. Такође је завршена техничка припрема за објављивање 41. књиге Археоiрафских йрилоїа (за 2019). Настављени су послови на реконституцији тзв. Старе збирке Народне библиотеке у Београду, допуњавана је литература за поједине рукописне књиге.

Сарадници Одељења највећи део радног времена посветили су научноистраживачком раду у ужем смислу. Радили су на следећим темама: успостављање теоријског приступа археографској обради поменичких књига: анализа књига за уписивање милостиње из збирке Библиотеке Епархије будимске у Сентандреји; текстологија оригиналне српске средњовековне књижевности: текстолошка анализа и поређење различитих преписа службе архиепископу Јевстатију; каталог орнаментике српских рукописних књига XIV и XV века: опис илуминације (заставица и иницијала) рукописа манастира Дечана; језик и писмо у повељама и писмима краља Милутина из Дубровачког архива; венецијанска издања српског штампарства XVI века: садржина издања Божидара Вуковића; писање одредница за Православну енциклопедију (Русија).

Одржаван је редован контакт са корисницима у вези са њиховим истраживањима, електронским или телефонским путем. 


\section{Сектор Виртуелна библиотека Србије}

У Сектору Виртуелна библиотека Србије свакодневно је обављана комуникација са кандидатима за лиценцирање за рад у систему узајамне каталогизације на COBISS платформи, што подразумева пружање стручне и техничке помоћи за рад у онлајн тестном окружењу. Обављана је електронска комуникација са Комисијом за лиценце за узајамну каталогизацију и прегледани су тестни записи за добијање лиценци, па је у извештајном периоду додељено осам лиценци (ДУКА- дозвола А) библиотекарима, a 10 библиотекара су у поступку за стицање лиценце.

Редовно је ажуриран Портал Образовања COBISS.SR, уз постављање нове верзије Апликације портала и обављање административних послова на ажурирању корисничких налога и шифрарника. Постављен је план курсева за 2020. годину, уз онлајн преузимање пријава за планирану лиценцирану обуку. Свакодневно је пружана стручна и техничка помоћ библиотекарима, активним учесницима у Систему узајамне каталогизације путем мејла vbsservis@vbs.rs или телефона. У оквиру извођења аутоматизовене ревизије фонда НБС, пружана је стручна помоћ колегама који су укључени у овај процес, уз генерисање извештаја о ревизији.

Рад у Одељењу за развој рачунарско-информатичког система одвијао се по плану на пословима подршке информационом систему НБС. Због наступања ванредног стања у држави, и доношења одлуке од стране Народне библиотеке Србије за рад од куће, запосленима у НБС је омогућен удаљени приступ са кућних рачунара и службених лаптопа. Најважније активности односиле су се управо на даљинско праћење ИТ инфраструктуре НБС уз одржавање мејл сервера и контролу даљинске комуникације запослених са ИТ инфраструктуром. Телефонски је пружана помоћ корисницима, како да приступе одређеним НБС сервисима преко интернета; праћена је безбедност рачунарске мреже НБС и решавани проблеми настали добијањем порука малициозног садржаја; омогућен је рад од куће свим корисницима, који су за тим имали потребу, креирањем групне полисе на доменима nb.int и nbs.int, којима се омогућава удаљени приступ Remote Desktop Users.

За одређени број корисника креирани су VPN налози, којима се омогућава сигуран и заштићен приступ НБС серверима и радним станицама. Beћем броју корисника је инсталиран програм TeamViewer, на кућним рачунарима и на рачунарима на којима раде у Библиотеци, чиме им је омогућено да несметано раде свакодневне послове као да су физички на радном месту. 
У оквиру припрема за реализацију стручних испита обављане су редовне консултације са кандидатима за мајски стручни испит, прегледана је њихова документација (послата у електронској форми) и давана су упутства о поступању. Настављени су и радови на дотеривању перформанси нове апликације за Мрежу библиотека Србије.

Дигитална НБС у време корона вируса била је усмерена ка ревидирању и промовисању садржаја Дигиталне НБС на сајту НБС. У склопу сређивања садржаја на дигиталној библиотеци, додати су описи за наслове периодике, односно дигиталне збирке свуда где недостају, као и преводи тих описа на енглески језик. Преведени су описи за следеће наслове периодике: Пијемонй, Геиа, Раgник, Тойлике новине, Оріанизовани раяник, Илустировани листи, Наяреализам данас и овgе, Вечности, Данас, Албанска

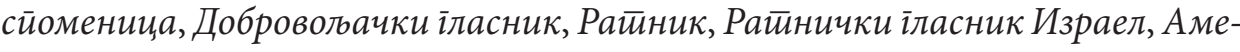
рикански Србобран, Бошюак, Нарояна свијесит, Борба, Зенити, Даgа Танк, Хийнос, Пуйеви, Даgа-Јок, Свеgочанстива, Бела ревија. Подигнути су ПДФ документи експортовани из docWorks-a и они који су генерисани директно из скенираних слика за годишта Женскої иокрет̄ $a$, од 1927. до 1938. године, укупно 106 бројева, односно претраживих и сликовних ПДФ докумената.

Статистика приступа садржајима Дигиталне НБС говори да је збиркама приступило 19.676 јединствених корисника (18.704 нова корисника). У априлу, евидентиран је 17.071 кориснички захтев (15.238 нових корисника), а током прве половине маја, 4.229 јединствених посетилаца (3.113 нових корисника). Пораст посете (просечан број посетилаца претходних месеци био је око 5.000) узрокован је мерама ванредног стања, када су људи преоријентисани на дигиталне сервисе, а Дигитална НБС промовисана је на националном порталу Дигитална солидарност https://www.digitalnasolidarnost. gov.rs/usluge/narodna-biblioteka-srbije/.

Редовно су се реализовале онлајн активности у вези са европским пројектима у које је укључена НБС: Заједничка култура у Европеани (текући пројекат, због пандемије продужен до краја 2020. године), Процват писмености, а ADRINETBOOK, пројекат који је поднет у јулу 2018. године кроз програм финансирања INTERREG V-B Adriatic-Ionian ADRION Programme 2014-2020, одобрен је за финансирање уз извесне измене, које су дефинисане крајем 2019. године. 


\section{Сектор за заједничке програме}

У оквиру Службе за издаваштво вршен је рад на припреми за штампу (лектура и коректура, техничка припрема) преосталих публикација из издавачког плана за 2019. годину: Срӣска библиоірафија: кюиїе 1801-1867. Том II; фототипско-транскрибовано издање рукописног листа Рововач; периодична публикација Археоірафбски иррилози бр. 41;

Сйрашна комеgија. Прейиска Анушке Кон Мицић и Љубомира Миuића 1920-1960. фототипско издање књиге Нароgне иіре VII Љубице и Данице Јанковић; фототипско издање књиге Нароgне иіре VIII Љубице и Данице Јанковић, као и рад на припреми публикација обухваћених издавачким планом за 2020. годину.

Служба за пласман књиге и маркетинг редовно је постављала све релевантне садржаје са веб-сајта Народне библиотеке Србије на друштвене мреже (Фејсбук и Инстаграм). Тим путем обележен је и Дан сећања на страдање НБС у Другом светском рату, са видео-поруком управника НБС као средишњим делом. Вршена је и припрема материјала за онлајн представљање одржаних изложби НБС и пратећих садржаја, као и прикупљање, ажурирање и сређивање грађе за предстојеће изложбе, односно изложбене каталоге, уз осмишљавање адекватне колекције сувенира у складу са дугорочним планом визуелног представљања Народне библиотеке Србије.

Служба за програме из културе и односе с јавношћу вршила је припрему планираних садржаја (изложба планирана у сарадњи са Министарством културе и информисања Републике Србије и Форума словенских култура), као и припрема виртуелног обележавања значајних датума, попут Светског дана књиге и ауторских права, и презентације различитих књижевних садржаја у виртуелној области (представљање различитих публикација, књижевних стваралаца...). Обележавање Дана страдања НБС адекватно је медијски пропраћено: материјал, са видео-поруком управника НБС, емитован је у свим информативним терминима РТС-а; вести и информације о обележавању Дана страдања НБС објављене су у већини штампаних медија.

На друштвеним мрежама НБС свакодневно су, поред дигиталних садржаја НБС, издвајани линкови различитих емисија из културе, пре свега у области књижевности, које се доводе у везу са НБС. 


\section{Ка повратку у физичку димензију}

Искуства у раду стечена током ванредног стања послужила су и након повратка на рад у просторијама Народне библиотеке Србије. Наиме, нови талас појачане циркулације вируса довео је до тога да запослени са хроничним болестима још једном буду упућени на рад од куће и то крајем јуна и почетком јула, те је у том смислу било неопходно организовати послове за рад на даљину и обезбедити контролу ових процеса. Поред тога, погоршање епидемиолошке слике које се очекује након периода сезонских инфекција такође најављује и потребу да се искуства стечена током пролећа 2020. анализирају и унапреде, а инфраструктурни и организациони услови за рад на даљину побољшају. Увид у међународну праксу такође је донео нове идеје које се могу применити на пословање Народне библиотеке Србије. Остаје да се ради на одржавању позитивног духа и атмосфере, поспешивању колегијалних односа и очувању интегритета институције који у свакој ситуацији која тектонски уздрма друштво имају тенденцију да клону. Формално ванредно стање је укинуто, али оно је суштински наставило да буде ванредно; могуће га је превазићи радом, дисциплином и међусобним уважавањем на чему ће настојати и Народна библиотека Србије. 


\title{
Dragana D. Milunović
}

National Library of Serbia, Belgrade

dragana.milunovic@nb.rs

\section{NATIONAL LIBRARY OF SERBIA DURING THE STATE OF EMERGENCY DECLARED ON THE OCCASION OF THE COVID 19 PANDEMIC}

\begin{abstract}
The paper deals with description of the work process organization, as well as the results of the National Library of Serbia achieved during the state of emergency declared on the occasion of the COVID 19 pandemic. The workflow of NLS departments, necessary infrastructure to work remotely, as well as the application of epidemiological measures to protect employees, users and the book fund are also described.
\end{abstract}

Keywords: pandemic, national Library of Serbia, epidemiological measures.

Примљено: 6. августа 2020. Исправке: 29. септембра 2020. Прихваћено: 10. октобра 2020. 